\title{
Changes in sooty shearwater Puffinus griseus chick production and harvest precede ENSO events
}

\author{
P. O'B. Lyver ${ }^{1, *}$, H. Moller ${ }^{1}$, C. Thompson ${ }^{2}$ \\ 'Department of Zoology, University of Otago, PO Box 56, Dunedin, New Zealand \\ ${ }^{2}$ Department of Mathematics and Statistics, University of Otago, PO Box 56, Dunedin, New Zealand
}

\begin{abstract}
A large-scale decline in the population of an apex marine predator, the sooty shearwater Puffinus griseus, in the North Pacific was corroborated by decreased harvest rates of a muttonbirder between 1979 and 1998 in New Zealand. Between 1989 and 1998 harvest rates decreased by $47 \%$ in the nanao (burrow prospecting) period and $42 \%$ in the rama (nightly capture of emerging chicks) period. The number of muttonbirders harvesting on Poutama Island decreased over the $20 \mathrm{yr}$ as chicks became scarcer, suggesting that the harvest is potentially self-regulating. Chick abundance on an unharvested island also declined over the last decade, suggesting that harvest was not a sufficient sole cause for the decline. Changes in harvest rates and burrow occupancies between successive years significantly predicted the direction and intensity of Southern Oscillation and sea-surface temperature anomalies in the following $12 \mathrm{mo}$. Climatic perturbations may affect food availability, predominant wind characteristics, direct and indirect fishery pressure and $\mathrm{PCB} / \mathrm{DDE}$ redistribution in sooty shearwaters.
\end{abstract}

KEY WORDS: Sooty shearwater - Harvest rate decline - Southern Oscillation - Climatic perturbations

\section{INTRODUCTION}

Marine birds are sensitive to perturbations in climate, prey abundance and food-web structure (Crawford \& Shelton 1978, Cairns 1987, Furness 1987, Aebischer et al. 1990, Montevecchi 1993, Ainley et al. 1996, Montevecchi \& Myers 1996, 1997). For example, changes in population size or reproductive ecology of seabirds may in some circumstances reflect changes in prey availability (Vader et al. 1990. Hunt et al. 1991, Montevecchi \& Myers 1997). Their role as indicators is enhanced by their longevity, mobility, large accessible populations and response to anomalies (Furness et al. 1993, Ainley et al. 1996).

The large-scale decline in the number of sooty shearwaters (titi) Puffinus griseus counted in the North Pacific in recent decades indicates a major fluctuation in the ocean ecosystem (Veit et al. 1996, 1997). Similar recent declines have also been reported for many other

\footnotetext{
- Present address: Natural Resources Institute, University of Manitoba, Winnipeg, Manitoba R3T 2N2, Canada

E-mail: lyverphil@netscape.com
}

seabird species around the Pacific Ocean (Ainley et al. 1994, Veit et al 1996). The mechanism(s) for these changes however have yet to be fully understood. Fisheries bycatch (from long-lining and gill-nets; King 1984, Tennyson 1990, DeGange et al. 1993, Murray et al. 1993) and overfishing of important seabird prey species by commercial fishers (Crawford \& Shelton 1978, MacCall 1982), climatic anomalies such as El Niño events disrupting marine foodwebs (Barber and Chavez 1986, Ainley et al. 1994, Veit et al. 1997), pollutants (Bourne 1976, Furness 1993) and long-term harvesting are all potentially cumulative impacts that could decrease seabird populations.

Sooty shearwaters are highly abundant trans-equatorial migrants and one of New Zealand's most important seabirds in terms of biological significance (Falla et al. 1978, Warham \& Wilson 1982). Burrowing, guano deposition and disruption of vegetation regeneration make them keystone species on some islands around southern New Zealand where they breed.

According to tradition, Rakiura Maori (the indigenous people from the southernmost part of New Zealand) have harvested sooty shearwaters since prehis- 
toric time from islands adjacent to Stewart Island (Wilson 1979, Anderson 1997). Customary use rights allow only Rakiura Maori to harvest chicks between 1 April to the 31 May of each year (Department of Lands and Survey 1978, Wilson 1979, Beattie 1994).

Very few scientifically measured demographic data have been recorded to estimate sooty shearwater population trends or proportion of chicks harvested. Therefore, the only consistent records that exist are those with muttonbirders that have kept diaries of harvest tallies or harvest rates. Some of these records are long-term, which could provide a valuable insight into trends of sooty shearwater quality and quantity over the years.

Trends in harvest rates and harvest intensity over a 20 yr period (1979-98) on Poutama Island were assessed. Burrow occupancy and chick mass data from Whenua Hou, an island where no harvest occurs, are also presented to test whether muttonbirding is a sufficient explanation for declines in bird abundance. We tested for correlations between annual variations in harvest rates, burrow occupancies and chick quality with the frequency and intensity of environmental phenomena such as El Niño Southern Oscillation (ENSO) events and resulting sea-surface temperature anomalies (SSTA).

\section{METHODS}

Study location. Poutama (Evening Island) is a 'beneficial' island (an island to which only certain Rakiura families have right of access) which is located in the south-western Rakiura Titi (Muttonbird) Island group approximately $5 \mathrm{~km}$ west of the southern tip of Stewart Island (Fig. 1). The island operates under an 'open

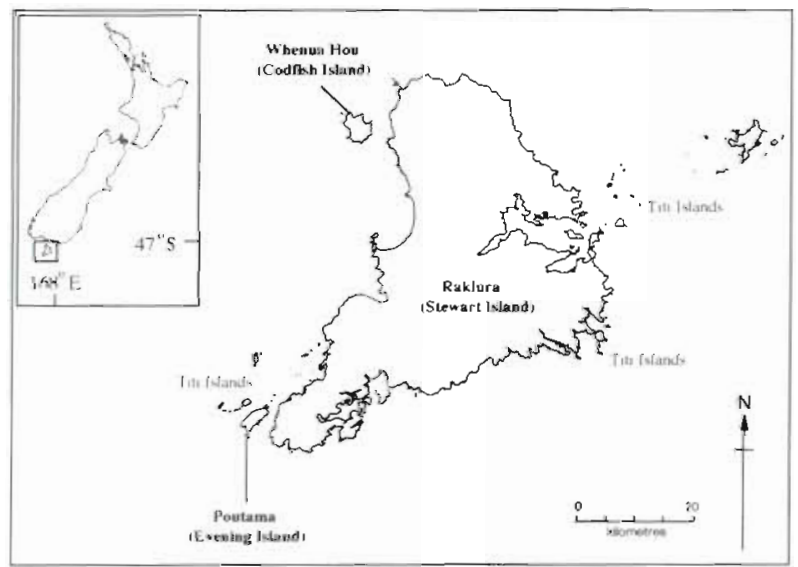

Fig. 1. Rakiura (Stewart Island) and adjacent Titi (Muttonbird) Islands showing the study locations, Poutama (Evening Island) and Whenua Hou (Codfish Island). Inset: map of New Zealand manu' system ('manu' means birding ground, so it is a system where muttonbirders can harvest chicks from anywhere on the island at any stage of the season). The island is approximately $60 \mathrm{ha}$, and predominantly covered in 'muttonbird scrub' species such as tete-aweka Olearia angustifolia and tupare Olearia colensoi grandis (Lyver unpubl. data). Whenua Hou (Codfish Island; $46^{\circ} 46^{\prime} \mathrm{S}, 167^{\circ} 38^{\prime} \mathrm{E}$ ) is a 1396 ha nature reserve (Southland Conservation Board 1994) located on the north-western side of Stewart Island (Fig. 1). The island is covered in a mixed forest which consists of southern rata Metrosideros umbellata, kamahi Weinmannia racemosa, podocarps (rimu Dacrydium cupressinum, miro Prumnopitys ferruginea, and totara Podocarpus cunninghamii), muttonbird Scenecio reinoldii, Olearia spp. and coastal Hebe elliptica scrub species and a diverse coastal understorey of Asplenium spp. (Meurk \& Wilson 1989). No harvest occurs on Whenua Hou.

Harvest estimates for 1994 and 1995. Eighty random transect points were selected around Poutama Island to assess burrow occupancy. At each transect the occupancy of the first 10 usable burrow entrances (entrances not blocked by soil) encountered within $1 \mathrm{~m}$ of either side of the transect centreline were determined using an infra-red burrowscope. This apparatus consists of a miniature camera and infra-red light source mounted on a length of flexible tube that is inserted down the burrow (see Lyver et al. 1998 for the design of the burrowscope). An image of the burrow contents is projected to a visual display unit at the surface.

In 1994 only 184 burrows ( 13 transects -130 burrow entrances) were sampled because of equipment restrictions. In 1995, 526 burrows (38 transects-380 burrow entrances) were surveyed for chicks. Burrows were described as 'occupied' (presence of a chick), 'unoccupied' or of 'unknown' (burrows where some underground characteristic, burrow corner or root, halted camera progress before the burrow end or a chick was reached) status. The survey was conducted in a $2 \mathrm{wk}$ period before the commencement of the harvesting ( 1 April) each year.

The total number of usable burrows (burrows $>0.2 \mathrm{~m}$-shortest burrow found with a chick) on Poutama each year was estimated using $2 \mathrm{~m}^{2}$ circular survey plots at each of 80 transect points. The total number of survey plots required to cover the $600000 \mathrm{~m}^{2}$ of Poutama's ground area was estimated and multiplied by the number of burrows in each of the 80 circular transects. From these, the average total burrow number was calculated.

The total number of chicks present each season was estimated on Poutama from burrow occupancies and total burrow counts. An estimate for the total number of chicks harvested was also obtained from muttonbirders on Poutama each year. Reliable daily harvest 
totals were reported by the muttonbirders in 1994 however, in 1995 catch totals from only 3 of the 7 birding families were consistently reported. A daily estimate was made for the other families taking into account the number and age of muttonbirders in the family, the length of time they harvested and weather conditions at the time. The estimates were also based on the number of chicks caught by the other muttonbirders for which we had definite daily totals. This enabled the proportion of chicks removed to be estimated each season.

Long-term harvest trends. One muttonbirder ('Birder $\mathrm{A}^{\prime}$ ) recorded harvest totals and the time worked each day on Poutama during the nanao (period where chicks are extracted from burrows during the daytime between 1 April and 20 April) and rama (period where chicks are caught between 21 April and 31 May at night on the ground's surface as they emerge from burrows to fledge) over a 20 yr period, 1979 to 1998 . The number of chicks harvested each year by Birder $\mathrm{A}$ in the nanao and rama periods were converted to mean annual daily harvest rates (average number of chicks caught per day per year). This allowed an estimate of population change over the 20 уг period to be determined. Nanao and rama harvest rates were analyzed separately because of the different chick capture techniques used.

Harvest rates were assessed on a daily basis because effort data was not available for the nanao in earlier years (1978 to 1988). The 'Lowess' (locally weighted regression scatterplot smoothing) regression procedure (Cleveland 1979) was applied to the raw nanao and rama daily harvest rate data to smooth fluctuations and provide an estimate for a point of inflection. The 'dummy variable' procedure, as described in Draper \& Smith (1981), was used to provide the slope of the trend and determine the exact point of inflection.

Differences in the proportion of chicks removed during the nanao and rama between 1989 and 1994 and 1989 and 1995 were used to estimate the change in harvest intensity on Poutama. The 1989 estimate represented the seasons between and including 1979 to 1989. The procedure for calculating the change in harvest intensities was (e.g. nanao 1994):

(1) Proportion chicks harvested by Birder A 1994

$$
P_{\text {A94 }}=\frac{\text { Birder A tally } 1994}{\text { chicks available } 1994}
$$

(2) Chicks available 1979-1989

$A_{89}=$ chicks available 1994

$\times \frac{\text { Birder A mean daily catch rate 1979-1989 }}{\text { daily catch rate } 1994}$

(3) Proportion chicks harvested by Birder A during $1979-1989$

$P_{\mathrm{A} 89}=$ mean nanao tally Birder A 1979-1989
(4) Total proportion chicks harvested 1979-1989

$T_{89}=\left(P_{\mathrm{A} 89} / P_{\mathrm{A} 94}\right) \times$ total proportion chicks harvested 1994

(5) Adjusted $T_{89}$

Adj. $T_{89}=$

mean number harvesters between 1979-1989 $\times T_{89}$ number of harvesters 1994

(6) Change in harvest intensity

Decline $=1.0-$ total proportion chicks harvested 1994

or adj. $T_{89}$

Increase $=$ total proportion chicks harvested 1994 adj. $T_{89}$

Effect of climatic anomalies. Harvest rates: Birder A's annual harvest totals for the nanao and rama were converted to hourly harvest rates (i.e. the average number of chicks caught per hour in each period each season). Hourly harvest rate was used instead of a daily harvest rate to avoid bias caused by different lengths of time worked each day during a season. Each mean annual hourly harvest rate was then subtracted from the year preceding it to reflect the relative chick abundance from the previous season. We assume a directly proportionate relationship between harvest rate and chick abundance.

The Southern Oscillation Index (SOI) used in this paper is based on the sea-level pressure differences between Tahiti and Darwin, Australia (Walker 1924), and standardized using a $60 \mathrm{yr}$ base (1933 to 1992) with respect to mean monthly standard deviations (Troup 1965, Chen 1982, National Climate Centre 1998). This anomaly index measures the frequency, intensity and length of climatic anomalies (El Niño and La Niña phenomena) operating over the Pacific. We used mean SOI anomalies for the 12 mo running from June to May. This period represents the time in which sooty shearwaters would be exposed to SOI environmental conditions before the harvest in the following season (April to May). Our annual index of anomalies was then used to predict the observed variation in annual harvest rates.

SSTAs for the area $5^{\circ} \mathrm{N}$ to $5^{\circ} \mathrm{S}, 160^{\circ} \mathrm{E}$ to $150^{\circ} \mathrm{W}$ were obtained from the Sea-WiFS satellite network (Goddard Space Flight Centre 1998). These temperature anomalies were also averaged over $12 \mathrm{mo}$, running from June to May. Average SSTA were correlated with the SOI data to model the change in sea-surface temperatures (SSTs) in the western Pacific during each phase of the oscillation.

Other predictor variables such as the (1) number of days worked $_{i}(2)$ amount of time (min) that the moon was above the horizon; (3) number of nights where the lunar phase was greater than half; (4) number of nights with wind described as $\geq$ moderate in strength; (5) number of nights with precipitation; and (6) number of nights with visible aurorae were recorded for each season during the rama. 
Burrow occupancy on Whenua Hou: Sooty shearwater burrow occupancy data from March/April each season was gathered by the Department of Conservation (DoC) staff from 1986 to 1996 on Whenua Hou (Codfish Island). Although the Whenua Hou data have been shown to be unreliable as an estimate for absolute occupancy (Hamilton et al. 1996), it can be used as a relative index of chick numbers. Methodology (same burrows surveyed each year using the same techniques for locating chicks) and effort was consistent through the years, although field staff did change. Sampling occurred in March/April of each year, which meant the chicks were surveyed and caught on the unharvested and harvested islands at approximately the same time.

Chick quality: The masses of sooty shearwater chicks extracted from burrows were measured by DoC staff on Whenua Hou, mostly from mid- to late March. Chick quality on Poutama was assessed using the muttonbirder's own grading system. When muttonbirders pack chicks for storage they grade them by size into ' $A$ ' (large), 'B' (medium) and ' $\mathrm{H}$ ' (home) categories. Chicks that are small or damaged in some way are graded as 'home' birds. The quality of chicks each season was determined using the percentage of the annual catch (excluding home birds) that was Grade A.

Chick quality during a season may also provide an indication of the health of the local marine food resources used by sooty shearwaters. To assess if there was any relationship between chick quality and climatic variability, chick masses and the percentage of the annual harvest made up by Grade A chicks were individually modelled with the SOI and SST anomalies. To check for inter-island variation annual chick masses from Whenua Hou were correlated with the corresponding percentage of the annual harvest made up by Grade A chicks from Poutama Island.

\section{RESULTS}

\section{Annual harvest trends}

The Lowess regression indicated increasing and stable trends in daily harvest rates from the nanao and rama respectively during the 1980 s, and declining trends in both periods during the 1990s. The model used also identified the years between 1988 and 1992 as potential points of inflection and explained the greatest amount of variation $\left(r^{2}=37 \%\right)$. The 'dummy variable' regression procedure provided the expected slopes of the 2 trend lines and indicated 1989 as the exact point of inflection (Fig. 2). Daily nanao harvest rates significantly increased between 1979 and 1989 , but thereafter declined dramatically (Table 1, Fig. 2). Annual daily harvest rates in the rama showed little

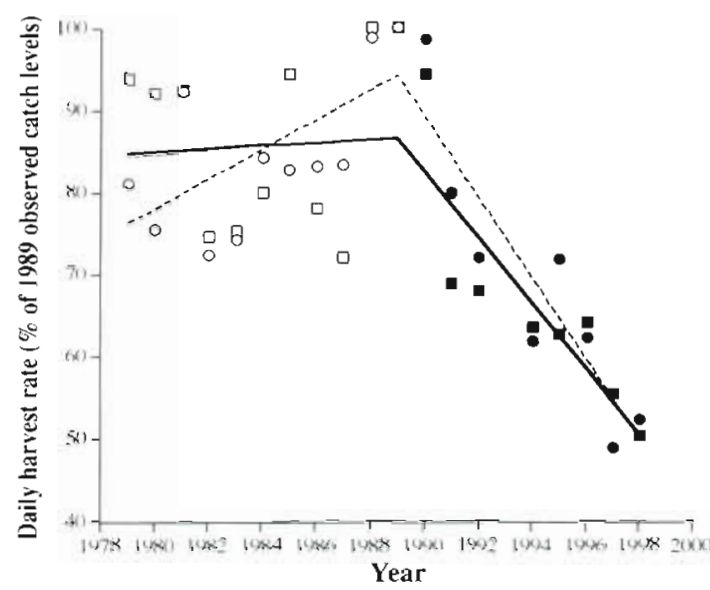

Fig. 2. Trend in expected annual daily harvest rate percentages for the nanao (-...-) and rama (-) periods between 1979 and 1998 on Poutama Island. (O) Observed nanao daily harvest rates prior to 1989 ; $(\bullet$ ) post 1989 . ( $(\square)$ observed rama daily harvest rates prior to $1989_{i}$ ( $)$ post-1989

evidence of an increase in the years prior to 1989 (Table 1, Fig. 2), but decreased sharply in the years following. Harvest rates declined by $47 \%$ in the nanao and $42 \%$ in the rama between 1989 and 1998. The number of hours worked per day and days worked per year by the muttonbirder in the nanao and rama have remained consistent throughout the years recorded (Table 2). A similar pattern of decline was observed in burrow occupancy between 1988 and 1996 on the unharvested island Whenua Hou (Fig. 3).

Harvest intensity estimates (\% chicks harvested) in the nanao declined from $17 \%$ prior to 1989 to $7 \%$ in 1994 , and from $11 \%$ prior to 1989 to $8 \%$ in 1995 . These represent declines of 61 and $33 \%$ respectively. Similar declines were shown between years in the rama period. Harvest intensities decreased from $26 \%$ prior to 1989 to $18 \%$ in 1994 , and from $28 \%$ prior to 1989 to $25 \%$ in 1995 . These represent a 30 and $12 \%$ decline in the percentage of chicks harvested respectively.

Table 1. Linear regression coefficients describing trends in daily harvest rates on Poutama Island for the nanao and rama periods between 1979 and 1989 and from 1989 to 1998 The inflection point at 1989 was identified using a 'dummy variable' regression procedure

\begin{tabular}{|lrrrr|}
\hline Predictor & Coefficient & $\mathrm{SD}$ & t-ratio & p-value \\
\hline Nanao & & & & \\
Constant & 128.510 & 2.489 & 51.63 & $<0.0001$ \\
$1979-1989$ & 2.473 & 0.455 & 5.43 & $<0.0001$ \\
$1990-1998$ & -6.753 & 0.501 & -13.47 & $<0.0001$ \\
Rama & & & & \\
Constant & 138.373 & 6.512 & 21.25 & $<0.0001$ \\
$1979-1989$ & 0.313 & 1.199 & 0.26 & 0.7940 \\
$1990-1998$ & -6.402 & 1.276 & -5.02 & $<0.0001$ \\
& & & & \\
\hline
\end{tabular}


Table 2. Average daily and yearly effort estimates and ranges for hours and

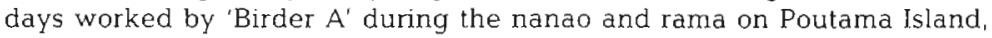
1979 to 1998

\begin{tabular}{|c|c|c|c|c|}
\hline & \multicolumn{2}{|c|}{ Nanao } & \multicolumn{2}{|c|}{ Rama } \\
\hline & $\begin{array}{l}\text { Hours worked } \\
\text { (per day) }\end{array}$ & $\begin{array}{l}\text { Days worked } \\
\text { (per season) }\end{array}$ & $\begin{array}{l}\text { Hours worked } \\
\text { (per day) }\end{array}$ & $\begin{array}{c}\text { Days worked } \\
\text { (per season) }\end{array}$ \\
\hline Mean & 6.45 & 17.37 & 3.64 & 18.74 \\
\hline SE & 0.13 & 0.34 & 0.10 & 0.53 \\
\hline $\mathrm{n}$ & 8 & 19 & 19 & 19 \\
\hline Range & $5.81-6.83$ & $14-19$ & $2.94-4.30$ & $14-22$ \\
\hline
\end{tabular}

La Niña event would be predicted for Year $t+2$. If harvest rates declined dramatically, an intense El Niño anomaly would be predicted for the Pacific in the 12 mo (June to May) following. The prediction holds for both the probability of an El Niño/La Niña, and for its intensity (i.e. a greater change in harvest rate predicts a more intense ENSO event in the following year).

We further tested the reliability of our regression with a 1-sided Durbin-Watson test to detect if positive autocorrelation

\section{Effect of climatic fluctuations on harvest rates during the rama}

There was no significant relationship between average SOI anomalies and corresponding annual differences in hourly harvest rates. However, when harvest rate differences were lagged by 1 yr and regressed with average SOI anomalies the relationship became highly significant (Table $3 a$ ). The SOI was able to predict change in harvest rates between the 2 previous years and explain $76 \%$ of the variation in this response variable.

Harvests of sooty shearwaters cannot cause climate fluctuations. Accordingly, this model was reversed so that harvest rate differences were used as the significant predictor of the SOI. The coefficient of variation remains the same $\left(r^{2}=76 \%\right)$, with only slight changes in the co-efficient and standard deviation estimates (Table 3b). Increases in the SOI followed 1 yr after increases in harvest rates between years (Fig. 4). If harvest rates increased from Year $t$ to Year $t+1$, a

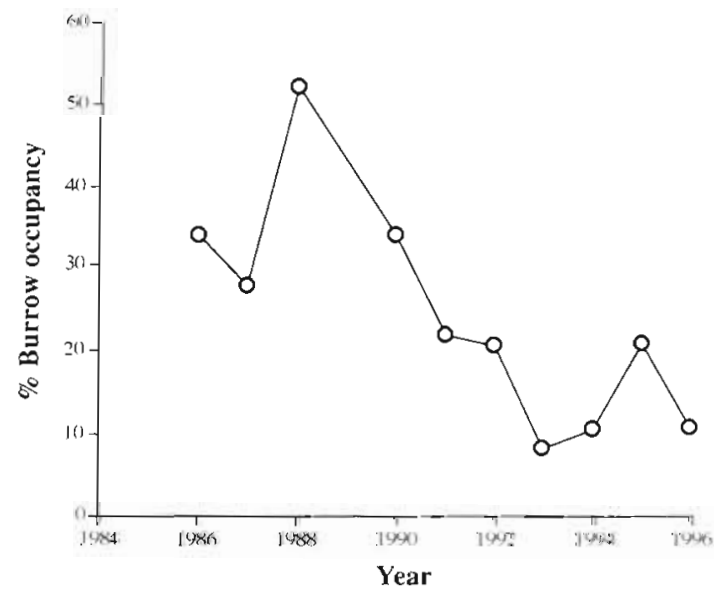

Fig. 3. Trend in percentage burrow occupancy obtained during the March/April period between 1986 and 1996 from Whenua Hou (Codfish Island). Data from the Department of Conservation, Invercargill (Hamilton et al. 1996, Cooper unpubl.) existed between annual harvest rate residuals. The test was not significant ( $\rho=2.450 ; k=1$; $\mathrm{n}=15$ ), indicating the assumption of independent model errors was not seriously violated.

No significant relationships were detected between harvest rate differences from the rama, when they were lagged by 2, 3, 4 and 5 yr, and modelled with the SOI. Similarly, no significant relationships were found between the SOI, when lagged by $2,3,4$ and $5 \mathrm{yr}$, and harvest rate differences. However, when the SOI was lagged by 1 yr a weakly significant relationship was detected (Table 4 ), which explained $25 \%$ of the variation in harvest rate differences.

SSTs were highly correlated with SOI values in the years from 1979 to $1998\left(r_{X Y}=-0.839 ;\right.$ df $=17 ; p=$ 0.001 ). In years of negative SOI anomalies (El Niño events) SST decreased in the western tropical oceanic zone described (Fig. 5). SST was highly significant when modelled with the lagged annual differences in

Table 3. Significance of using (a) the Southern Oscillation Index (SOI) to predict changes in lagged mean annual hourly harvest rate differences from the nanao and rama and; (b) lagged mean annual hourly harvest differences from the nanao and rama to predict changes in the SOI

\begin{tabular}{|c|c|c|c|c|c|}
\hline Predictor & Coefficient & SD & $t$-ratio & p-value & Years \\
\hline \multicolumn{6}{|c|}{$\begin{array}{l}\text { (a) Using SOI to predict lagged harvest rate difference } \\
\text { Nanao }\end{array}$} \\
\hline Constant & -0.14 & 1.04 & -0.13 & 0.904 & \\
\hline $\mathrm{SOI}$ & 0.295 & 0.108 & 2.72 & 0.072 & 5 \\
\hline \multicolumn{6}{|l|}{ Rama } \\
\hline Constant & 2.48 & 1.16 & 2.14 & 0.052 & \\
\hline SOI & 0.764 & 0.121 & 6.33 & $<0.0001$ & 15 \\
\hline \multicolumn{6}{|c|}{$\begin{array}{l}\text { (b) Using lagged harvest rate difference to predict SOI } \\
\text { Nanao }\end{array}$} \\
\hline Constant & -1.418 & 2.877 & -0.49 & 0.656 & \\
\hline $\begin{array}{l}\text { Lagged harvest } \\
\text { rate difference }\end{array}$ & 2.416 & 0.888 & 2.72 & 0.072 & 5 \\
\hline \multicolumn{6}{|l|}{ Rama } \\
\hline Constant & -3.406 & 1.203 & -2.83 & 0.014 & \\
\hline $\begin{array}{l}\text { Lagged harvest } \\
\text { rate difference }\end{array}$ & 0.989 & 0.156 & 6.33 & $<0.0001$ & 15 \\
\hline
\end{tabular}




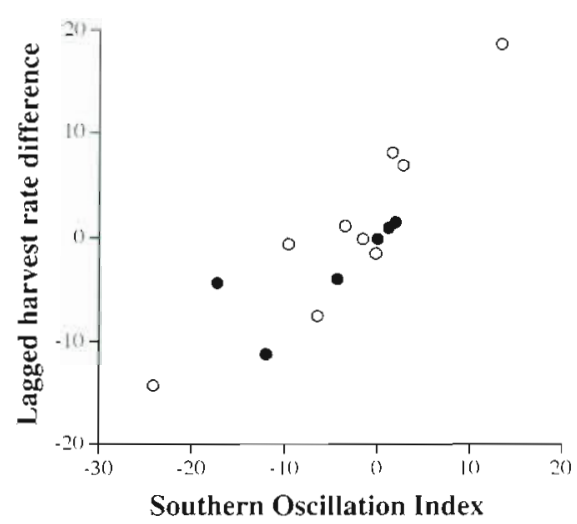

Fig. 4. Relationship between lagged annual hourly rama harvest rate differences and SOI anomalies from 1979 to 1998 on Poutama Island. (0) Lagged harvest rate differences prior 1989; (•) post 1989

harvest rates in the rama, explaining $71 \%$ of the response variation. However, a multiple regression model found that SST did not explain significant additional variation after SOI was accounted for. The high correlation between the predictor variables suggests that the multiple regression could not reliably determine whether SOI or SST, or some combination of both, best predict the previous year's change in harvest rate. The SOI was used because it is the over-riding climatic determinant for other conditions such as SST.

With the SOI in place as a covariate, each of the other predictor variables such as the number of days worked, lunar times and phases, and the number of rain, wind and aurorae nights were added to the General Linear Model. Interactions between these variables such as lunar phase $x$ lunar time and lunar phase $\times$ lunar time $\times$ rain nights were also tested. All were not significant and could not explain any additional variation in the response variable (change in harvest rates).

\section{Effect of climatic fluctuations on harvest rates during the nanao}

Hourly harvest rate information for the nanao regression model was only available for 9 (1989 to

Table 4. The significance of using the SOl lagged by 1 yr to predict changes in mean annual hourly harvest rate differences from the rama

\begin{tabular}{|lllll|}
\hline Predictor & Coefficient & SD & t-ratio & p-value \\
\hline Constant & -2.125 & 1.753 & -1.21 & 0.244 \\
SOl lag & -0.4779 & 0.215 & -2.22 & 0.042 \\
\hline
\end{tabular}

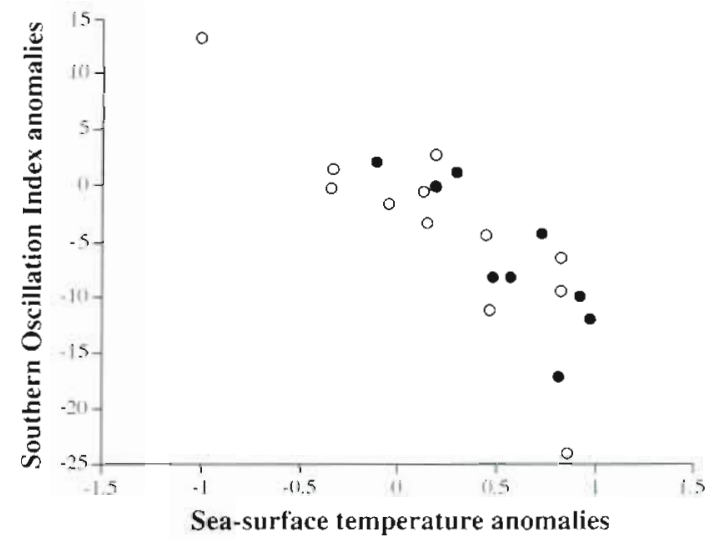

Fig. 5. Relationship between SOI and western Pacific seasurface temperature anomalies from 1979 to 1998. (O) Years prior $1989 ;(\bullet)$ post 1989

1998) of the 20 years. These data were further reduced to only 5 years when a missed season, differences between years and lagging were incorporated. This reduced the power of the model considerably, and is potentially the reason for the relationship between differences in lagged nanao harvest rates and the SOI not being significant (Table 3a,b). However, even with such a small sample size the test was almost significant at 0.072 , and the relationship explained $71 \%$ of the variance in the lagged harvest rate (Fig. 6). A 1-sided Durbin-Watson test indicated an absence of positive autocorrelation ( $\rho=2.680 ; k=1 ; n=5)$ in the residuals from the regression model.

We built a multiple regression model to predict change in nanao harvest rate from SOI and number of days worked each season. Only SOI was a significant predictor. Chicks remain underground throughout the nanao, and so are isolated from variables such as wind, rain, lunar and aurorae events.

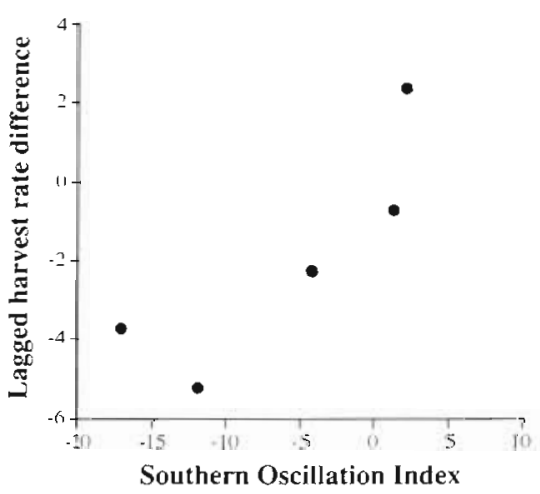

Fig. 6. Relationship between lagged annual hourly nanao harvest rate differences and SOI anomalies from 1989 to 1998 on Poutama Island. ( $\bullet$ Lagged harvest rate differences post 1989 


\section{Burrow occupancy on Whenua Hou}

Burrow occupancies from an unharvested population on Whenua Hou were collected between 1986 and 1996 and modelled with SOI anomaly averages. Annual burrow occupancy differences regressed with SOI anomalies were not significant; however when lagged by 1 yr the relationship became highly significant $(F=23.330 ; \mathrm{df}=6 ; \mathrm{p}=0.005)$ and accounted for $82 \%$ of the response variation (Fig. 7). Annual burrow occupancy differences were also significantly correlated with corresponding differences in harvest rates from Poutama $\left(r_{x y}=0.855 ; d f=4 ; p=0.050\right)$.

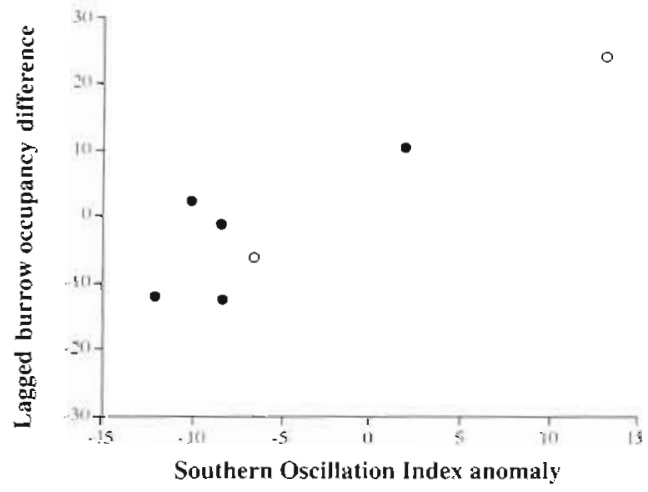

Fig. 7. Relationship between lagged annual burrow occupancy differences and SOI anomalies from 1986 to 1996 on Whenua Hou (Codfish Island). (0) Lagged burrow occupancy differences prior 1989; (•) post 1989

\section{Effects of climatic fluctuations on chick quality}

A significant positive linear correlation was found to exist between masses of chicks on Whenua Hou and the percentage of harvested chicks from Poutama that were Grade A (i.e. large chicks; $\mathrm{r}_{\mathrm{xy}}=0.709 ; \mathrm{df}=6 ; \mathrm{p}=$ $0.050)$. However, neither chick masses $(F=2.275$; $\mathrm{df}=8$; $\mathrm{p}=0.175)$ nor $\%$ Grade $\mathrm{A}(F=0.004 ; \mathrm{df}=19 ; \mathrm{p}=0.949)$ could significantly predict the SOI. When \% Grade A was lagged $1 \mathrm{yr}$, a potential, but weak relationship was detected $(F=3.091 ; \mathrm{df}=18 ; \mathrm{p}=0.097)$.

SST was also not significant when modelled as a separate predictor for \% Grade A on Poutama ( $F=$ 1.548; $\mathrm{df}=19 ; \mathrm{p}=0.229$ ) and for chick masses on Whenua Hou $(F=3.353 ; \mathrm{df}=8 ; \mathrm{p}=0.110)$.

\section{DISCUSSION}

\section{Decline in harvest rates and intensity}

Overall, harvest rates in the nanao and rama declined on Poutama Island between 1979 and 1998.
However, between 1979 and 1989 harvest rates increased in the nanao and remained stable in the rama. The increase in daily nanao harvest rates between 1979 and 1989 was consistent with the increasing trend in the annual densities of sooty shearwaters migrating south across the equatorial Pacific over the same period (Spear \& Ainley 1999). Large declines occurred after 1989 , with annual daily harvest rates falling by $47 \%$ in the nanao and $42 \%$ in the rama. It is unlikely that chicks have become harder to catch (behavioural shifts of this magnitude would take much longer to develop). Nor are the reduced harvest rates the result of reduced work effort (Table 2). Declines in harvest rates (Fig. 2) were also reported by other muttonbirders on Poutama, some of which were younger than Birder A, suggesting the declining trends were not the result of reduced work efficiency on Birder A's behalf. The decline probably directly reflects a reduction in chick abundance.

Some shearwaters skip breeding in some years (Wooller et al. 1990, Warham 1996), so it is theoretically possible that the decline we observed in chick numbers reflects higher non-breeding rates rather than a decline in adult numbers. If the trend we observed results from adults skipping breeding before El Nin̄o years we would have expected harvest rates to have rebounded to near their original levels in later years when a La Niña was coming. However, this is not the case (Fig. 2). This suggests that breeding birds were being lost from the population at a faster rate than they were being replaced.

The decline in harvest intensity on Poutama was attributed to both reduced chick harvest rates and a reduced number of harvesters. Between 1978 and 1998 the number of muttonbirders harvesting on Poutama declined steadily (by $60 \%$ in the nanao and $27 \%$ in the rama). This potentially indicates that some muttonbirders discontinued their harvest in response to falling harvest rates. If so, any impacts of muttonbirding on bird numbers may be self-regulating. If harvest impacts are indeed significant, any self-regulation could drive the population on each island to a lower equilibrium density. It is unknown whether mortality attributable to harvest is additive to impacts on mortality from climatic perturbations or whether mortalities compensate for each other. Decreased sooty shearwater abundance because of climatic impacts may also trigger increased reproductive rates if density dependence operates. The hypothesis of self-regulation of the harvest will be explored in subsequent studies using mathematical models and by interviewing muttonbirders to determine why some have chosen to discontinue birding in recent decades.

Harvest trends and intensities on other Titi Islands are needed before we can formally test whether the putative decline in sooty shearwater numbers is uni- 
versal. However, the closely parallel trend in chick occupancy monitored on Whenua Hou since 1989 suggests that widespread declines in sooty shearwater numbers have occurred (Fig. 3). As no muttonbirding occurs on Whenua Hou, it is clear that harvesting is unlikely to be a sufficient explanation in itself for the decline we have observed. Similarly, Veit et al. (1996) have documented declines in the number of sooty shearwaters and other seabirds feeding and travelling along the west coast of California between 1987 and 1994. Many colonies are not harvested; therefore, such a large change in bird abundance in the northern hemisphere is very unlikely to have been caused by harvesting of chicks alone. The geographical scale of Veit et al.'s (1997) study, where a $90 \%$ decline of adult sooty shearwaters was observed between 1987 and 1994 off western North America during the austral winter, suggests the trend is not a localized phenomenon, nor only a short-term distributional shift. However, it cannot be discounted that a change in distribution may have contributed to the observed change in bird numbers (Spear \& Ainley 1999).

We believe the decline in sooty shearwater numbers is much more widespread than on just Poutama and Whenua Hou because anecdotal reports of harvest declines come from 5 muttonbirders from 4 other islands. This was part of the motivation of Rakiura Maori in inviting this research project. Harvest records from other muttonbirders and their families are now being offered to the research team for similar analysis.

\section{Climatic impacts on sooty shearwaters}

The cause for the decline in sooty shearwater harvests may be linked to the increase in frequency, intensity and length of El Niño events during the past decade (Ittekkot 1996, Guilderson and Schrag 1998, B. Fitzharris pers. comm.). Accordingly, it is also possible that some other external factor has greatly depressed sooty shearwater numbers in the last 10 yr. A reversal in the 'Pacific Interdecadal Oscillation' which affects coastal sea temperatures in the North-east Pacific (Mantua et al. 1997) has been suggested as an alternative explanation (I. McKendry pers. comm.). We intend to assess this suggestion by analysis of historical anecdotes on sooty shearwater harvests throughout the century. Nevertheless, we think that this possible alternative explanation is very unlikely because (1) the isolated intense El Niño in 1982-83 was predicted by the decline in harvest rate between 1981 and 1982 ; (2) the same trends were observed within pre- and post-1989 periods in Figs. 4 \& 7 (compare distributions of shaded and open symbols); (3) no other major new threat since 1989 has been posited; and (4) the large geographic scale of the decline (as suggested by Veit et al.'s [1997] and our findings) suggests a widespread perturbation like climatic fluctuation is involved.

Climatic change has been a suggested cause for fluctuations and declines in numbers of other seabird populations (Boersma 1978, Duffy 1983, Shannon et al. 1984, Duffy 1990, Jarvis 1993, Veit et al. 1996, Montevecchi \& Myers 1997). However, the links may be considerably more complicated than straightforward trophic interactions (Ainley 1976, Aebischer et al. 1990, Ainley et al. 1995). Even so, several studies have found significant correlations between prey abundance and seabird reproductive biology (Harris 1969, Hunt \& Butler 1980, Anderson et al. 1982, Burger \& Piatt 1990, Cruz \& Cruz 1990). The oceanic and atmospheric mechanisms involved with an El Niño phenomenon in the eastern Pacific depress the thermocline and nutricline, causing the spatial redistribution and/or a decline in the abundance of sooty shearwater prey such as anchovies Engraulis spp. and sardines Sardinops sagax (Barber \& Chavez 1986, Philander 1990). Reduced prey availability during migration could decrease adult survival or reproductive success in the following season. However, sooty shearwater numbers and/or breeding success is reduced 12 mo prior to an El Niño event.

The climatic mechanism(s) preceding SOI anomalies are poorly understood (B. Fitzharris pers. comm.). Newell et al. (1982) found significant precursors in SST around the Pacific, such as warming (cooling) in the north-west subtropical Pacific up to $1 \mathrm{yr}$ preceding positive (negative) SOI anomalies. If these advanced precursors were to significantly alter prey availability to sooty shearwaters during their migration, the subsequent response may be a decrease in fecundity and survival before the associated SOI event is formally registered. La Cock (1986) found South African warmwater events tended to occur in the same years, or in the year before, occurrences of El Niño and downward trends in the SOI. Seabird mass mortalities and breeding failures in this area were also equally likely to occur the year before a Pacific El Niño as during the event itself. A decline in south-easterly tradewinds, and subsequent upwelling, was thought to reduce the abundance and distribution of fish stacks such as anchovies and cause food shortages for seabirds either in the same year as climatic perturbations or in the year before.

The absence of a relationship between chick quality and SST suggests that water temperature in the New Zealand region did not cause any major changes in prey availability that affected sooty shearwaters. Sooty shearwaters may be able to counter changes in prey availability and conditions by feeding on a broad range of prey species ( $T$. de Cruz pers. comm.), diving to depths of $67 \mathrm{~m}$ (Weimerskirch \& Sagar 1996) and most 
probably foraging extensively. Alternatively, our use of chick masses just prior to fledging as an environmental indicator of 'poor' years may be biased. A disproportionate number of heavy chicks may be measured in 'poor' compared with 'good' years because chicks of low mass are more likely to die before fledging (Williams \& Croxall 1990). This potential problem may have obscured a real effect of climate fluctuations on average chick masses in sooty shearwaters.

\section{Direct and indirect fishery pressure}

In many areas of the Pacific important sooty shearwater prey species such as anchovies (Chu 1982), and euphausiids Nictyphanes australis, N. capensis (Fenwick 1973) and Euphausia superba are increasingly subject to harvest by humans (Hunt et al. 1991, Ainley et al. 1994). Overfishing, especially in periods of climatic instability, may reduce availability of food to seabirds (Crawford \& Shelton 1978, Anderson et al. 1982, Safina et al. 1988). Sooty shearwaters have been reported to require particular prey types such as anchovies for pre-migratory fattening before their return south (Chu 1982). Fishery impacts may force a shift to lower calorie prey such as squid (i.e. Loligo spp.) and euphausiids in these crucial periods (Ainley et al. 1994), and thereby reduce sooty shearwater survival and subsequent reproductive success.

Sooty shearwaters are a common bycatch species in the Pacific (King 1984, Ogi 1984, Tennyson 1990). In the North Pacific squid drift nets alone annual mortality for sooty shearwaters was approximately $427000 \pm$ 312000 (De Gange et al. 1993). It is estimated the total annual mortality of sooty shearwaters in the North Pacific accounts for 1 to $5 \%$ of the total population. (Tennyson 1990). These estimates could potentially increase if there has been an over-wintering distributional shift of sooty shearwaters into the sub-arctic Pacific (Spear \& Ainley 1999).

In years of abnormal climatic events bycatch may become increasingly prominent as oceanic conditions concentrate fish and their predators (i.e. birds and humans) into smaller confined areas. The concentration of anchovies in El Niño years along the Peruvian and Chilean coasts is known to concentrate commercial fisheries and birds into the same areas, thereby increasing the risk of seabird bycatch (Duffy 1983, Culik \& Luna-Jorquera 1997).

\section{Energetics}

A change in the predominant wind direction and intensity during climatic anomalies may alter energy costs of flight (Furness \& Bryant 1996), feeding efficiency or the frequency of adults returning to the breeding colony to provision chicks. The predominant wind direction over a given area in relation to foraging methods and flight behaviour has been suggested as an important determinant of migration routes for seabirds (Spear \& Ainley 1997; see Spear \& Ainley 1999 for suggested migration routes of New Zealand sooty shearwaters). However, sooty shearwaters are believed to forage little or not at all en route to the southern hemisphere (King 1974). This is supported by the findings of Spear \& Ainley (1999), who observed $13 \%$ of sooty shearwaters (mean mass $=643 \mathrm{~g}$ ) foraging while migrating north in the austral autumn, and only $3 \%$ (mean mass $=812 \mathrm{~g}$ ) foraging while migrating south in the austral spring.

In normal and La Niña years there is a general westward movement of trade winds across the Pacific (McGlone et al. 1990), which may assist sooty shearwaters returning to New Zealand. In El Nino events these winds weaken or reverse, which could increase migration effort across the equatorial regions and reduce adult survival or breeding potential. If a headwind coincides with a heavy moult (sooty shearwaters can lose up to $12 \%$ of it's body mass in the moult--Chu 1982) and reduced food availability, adults may not have time to recuperate body condition and greater losses could occur during the migration.

\section{Pollutants}

Adult short-tailed shearwaters from Tasmania, Australia, were shown to have accumulated higher levels of PCBs and DDE (a major metabolite of DDT) compared with chicks (Tanaka et al. 1986). Bogan \& Newton (1977) reported the percentage of DDE located in the brain of sparrowhawks Accipiter nisus slowly increased with progressively less fat and was markedly higher in birds which contained less than $1.5 \%$ fat in their bodies. It was suggested that starving birds were more at risk from toxic shock because DDE was released into the body and brain as adipose reserves were mobilized. A similar effect could be occurring in sooty shearwaters during their migration, especially if the birds are stressed by food shortages caused by climatic perturbations.

\section{SUMMARY}

Our analysis of historical records has shown a remarkably strong correlation between changes in sooty shearwater harvests and climate. The main conundrum in our results is that the trend in harvests or bur- 
row occupancy predicts the direction and magnitude of SOI anomalies for the following 12 mo after May (i.e. after the end of the harvest season). We have suggested several hypotheses for potential mechanisms, but testing them will inevitably be hampered by a paucity of understanding of how El Niño/La Niñas develop. Conversely, the study of sooty shearwater movements and diets could provide indications of precursor conditions of ENSO events and help predict the intensity and duration of oceanographic fluctuations.

Declines in sooty shearwaters may be useful bioindicators of world climate change (Veit et al. 1996, 1997), especially if the frequency and intensity of ENSO events change as a result of global warming this century (Trenberth 1990, Ittekkot et al. 1996). Major declines in sooty shearwater abundance due to oceanographic change has potential serious implications for the population as well as for the longterm sustainability of traditional sooty shearwater harvests.

Acknowledgements. Special thanks must go to the muttonbirder who made the diary available, because this paper would not have been possible without these valuable and meticulous records. Thanks must also go to the Poutama muttonbirders who allowed this research to occur on their island. This project was funded primarily by New Zealand's Foundation for Research, Science and Technology. Funding was also received from the New Zealand Lotteries Board, Pacific Development and Conservation Trust, New Zealand Aluminium Smelters Ltd, Invercargill Licensing Trust and the University of Otago. Thanks must go to Prof. Blair Fitzharris and Dr Andrew Shaw for their advice on climate issues, Mike Imber, Jill West and Wynston Cooper for the use of their unpublished data, Brian Carter and associates from the Carter Observatory and Bob Evans and members of the Royal Astronomical Society of New Zealand. Many thanks must also go to the anonymous referees for their valuable advice and review of this manuscript.

\section{LITERATURE CITED}

Aebischer NJ, Coulson JC, Colebrook JM (1990) Parallel long-term trends across four marine trophic levels and weather. Nature 347:753-755

Ainley DG $(1976)$ The occurrence of seabirds in the coastal region of California. West Birds 7:33-67

Ainley DG, Sydeman WJ, Hatch SA, Wilson UW (1994) Seabird population trends along the west coast of North America: causes and the extent of regional concordance. Stud Avian Biol 15:119-133

Ainley DG, Sydeman WJ, Norton J (1995) Upper trophic level predators indicate interannual negative and positive anomalies in the California Current food web. Mar Ecol Prog Ser 118:69-79

Ainley DG, Spear LB, Allen SG (1996) Variation in the diet of Cassin's auklet reveals spatial, seasonal, and decadal occurrence patterns of euphausiids off California, USA. Mar Ecol Prog Ser 137:1-10

Anderson A (1997) Historical and archaeological aspects of muttonbirding in New Zealand. NZ J Archaeol 17:35-55
Anderson DW, Gress F, Mais KF (1982) Brown Pelicans: influence of food supply on reproduction. Oikos 39:23-31

Barber RT, Chavez FP (1986) Ocean variability in relation to living resources during the $1982-83$ El Niño. Nature 319 : $279-285$

Beattie JH (1994) Traditional lifeways of the southern Maori. Anderson A (ed). University of Otago Press, Dunedin

Boersma PD (1978) Breeding patterns of Galapagos Penguins as an indicator of oceanographic conditions. Science 200: $1481-1483$

Bogan JA, Newton 1 (1977) Redistribution of DDE in Sparrowhawks during starvation. Bull Environ Contam Toxicol 18: $317-321$

Bourne WRP (1976) Seabirds and pollution. In: Johnston R (ed) Marine pollution. Academic Press Inc Ltd, London, p 403-502

Burger AE, Piatt JF (1990) Flexible time budgets in breeding Common Murres: buffers against prey abundance. Stud Avian Biol 14:71-83

Cairns DK (1987) Seabirds as indicators of marine food supplies. Biol Oceanogr 5:261-271

Chen WY (1982) Assessment of Southern Oscillation sea-level pressure indices. Mon Weather Rev 110:800-807

Chu EW (1982) Sooty Shearwaters off California: diet and energy gain. In: Nettleship DN, Sanger GA, Springer PF (eds) Marine birds: their feeding, ecology and commercial fisheries relationships. Proc Pacific Seabird Group Symp, Seattle, WA. Canadian Wildlife Service, Ottawa, p 64-71

Cleveland WS (1979) Robust locally weighted regression and smoothing scatterplots. J Am Stat Assoc 74(368):829-836

Crawford RJM, Shelton PA (1978) Pelagic fish and seabird interrelationships off the coasts of south west and south Africa. Biol Conserv 14:85-109

Cruz JB, Cruz F (1990) Effect of El Niño-Southern Oscillation conditions on nestling growth rate in the Dark-rumped Petrel. Condor 92:160-165

Culik BM, Luna-Jorquera G (1997) Satellite tracking of Humboldt Penguins (Spheniscus humboldti) in northern Chile. Mar Biol 128:547-556

De Gange AR, Day RH, Takekawa JE, Mendenhall VM (1993) Losses of seabirds in gillnets in the North Pacific. In: Vermeer K, Briggs KT, Morgan KH, Siegel-Causey D (eds) The status, ecology, and conservation of marine birds of the North Pacific. Can Wildl Serv Spec Publ, Ottawa, p 204-211

Department of Lands and Survey (1978) The Titi (Muttonbird) Islands Regulations 1978/59. Land Act Regulations 1949, Government Publishing, Wellington

Draper NR, Smith H (1981) Applied regression analysis, 2nd edn. John Wiley \& Sons, Inc, New York

Duffy DC (1983) Environmental uncertainty and commercial fishing: effects on Peruvian birds. Biol Conserv 26:227-238

Duffy DC (1990) Seabirds and the 1982-1984 El Niño Southern Oscillation. In: Glynn PW (ed) Global ecological consequences of the 1982-83 El Niño-Southern Oscillation. Elsevier Oceanography Series, 52. Elsevier Science Publishers BV, Amsterdam, p 395-415

Falla RA, Sibson RB, Turbott EG (1978) A field guide to the birds of New Zealand and outlying islands. Collins, Auckland

Fenwick GD (1973) Plankton swarms and their predators at the Snares Islands (Note). NZ J Mar Freshw Res 12(2): 223-224

Furness RW (1987) Seabirds as monitors of the marine environment. In: Diamond AW, Filiou FL (eds) The value of birds. International Council for Bird Protection, (ICBP) Technical Publication Number 6. Cambridge, p 217-230

Furness RW (1993) Birds as monitors of pollutants. In: Furness 
RW, Greenwood JJD (eds) Birds as monitors of environmental change. Chapman and Hall, London, p 86-143

Furness RW, Bryant DM (1996) Effect of wind on field metabolic rates of breeding northem fulmars. Ecology 77:1181-1188

Furness RW, Greenwood JJD, Jarvis PJ (1993) Can birds be used to monitor environmental change? In: Furness RW, Greenwood JJD (eds) Birds as monitors of environmental change. Chapman and Hall, London, p 1-41

Goddard Space Flight Centre (1998) Sea-WiFS Project-current monthly atmospheric and sea surface temperature index values (nic.fb4.noaa.gov/data/cddb). Sea-Surface Temperatures, Monthly Nin̄o Data, NASA

Guilderson TP, Schrag DP (1998) Abrupt shift in subsurface temperatures in the tropical Pacific associated with changes in El Niño. Science 281:240-243

Hamilton S, Moller H, Charteris M, Cooper W (1996) Breeding colonies of Sooty Shearwater (Puffinus griseus) on Whenua Hou, Codfish Island. University of Otago Wildlife Management Report, No. 77. p 49

Harris MP (1969) Food as a factor controlling the breeding of Puffinus Iherminierj. Ibis 111(2):139-156

Hunt GL, Butler JL (1980) Reproductive ecology of Western Gulis and Xantus' Murrelets with respect to food resources in the southern Californian Bight. Calif Coop Oceanic Fish Invest Rep 21:62-67

Hunt GL, Piatt JF, Erikstad KE (1991) How do foraging seabirds sample their environment? Acta XX Congressus Internationalis Ornithologici, New Zealand Ornithological Congess Trust Board, Wellington, p 2272-2279

Ittekkot V, Jilan S, Miles E (1996) Oceans. In: Watson RT, Zinyowera MC, Moss RH, Dokken DJ (eds) Climate Change 1995. Impacts, adaptations and mitigation of climate change: scientific-technical analyses contribution of working group II to the second assessment report of the intergovernmental panel on climate change. Cambridge University Press, Cambridge, p 267-288

Jarvis PJ (1993) Environmental changes. In: Furness RW, Greenwood JJD (eds) Birds as monitors of environmental change. Chapman and Hall, London, p 43-85

King WB (1974) Pelagic studies of seabirds in the central and eastern Pacific Ocean. Smithson Inst Contrib Zool 158:66

King WB (1984) Incidental mortality of seabirds in gillnets in the North Pacific. In: Croxall JP, Evans PGH, Schreiber RW (eds) Status and conservation of the world's seabirds. International Conservation for Bird Preservation, Technical Publication No. 2, Cambridge, p 709-715

La Cock GD (1986) The Southern Oscillation, environmental anomalies, and mortality of two southern African seabirds. Clim Change 8:173-184

Lyver P, Hamilton S, McKenzie M, Dickson I, Dooher M, Broad T, Moller $\mathrm{H}$ (1998) Construction and reliability of an infra-red camera for examining petrel nests in burrows. Conservation Science Advisory Notes No. 209. Department of Conservation, Wellington, p 21

MacCall AD (1982) Seabird-fishery trophic interactions in eastern Pacific boundary currents: California and Peru. In: Nettleship DN, Sanger GA, Springer PF (eds) Marine birds: their feeding, ecology and commercial fisheries relationships. Proc Pacific Seabird Group Symp, Seattle, WA, p 136-148

Mantua NJ, Hare SR, Zhang $Y$, Wallace JM, Francies $R C$ (1997) A Pacific interdecadal climate oscillation with impacts on Salmon production. Bull Am Meteorol Soc 78(6): 1069-1079

McGlone M, Clarkson T, Fitzharris B (1990) Unsettled Outlook. New Zealand and the greenhouse effect. GP Books, Auckland
Meurk CD, Wilson H (1989) Codfish Island. In: Stewart Island. Biological Survey of Reserve Series, No. 18. Department of Conservation, Wellington, p 46-49

Montevecchi WA (1993) Birds as indicators of change in marine prey stocks. In: Furness RW, Greenwood JJD (eds) Birds as monitors of environmental change. Chapman and Hall, London, p 217-266

Montevecchi WA, Myers RA (1996) Dietary changes in seabirds reflect shifts in pelagic food webs. Sarsia 80 : $313-322$

Montevecchi WA, Myers RA (1997) Centurial and decadal oceanographic influences on changes in northern gannet populations and diets: implications for climate change. ICES J Mar Sci 54(4):608-614

Murray TE, Bartle JA, Kalish SR, Taylor PR (1993) Incidental capture of seabirds by Japanese southern bluefin tuna longline vessels in New Zealand waters, 1988-1992. Bird Conserv Int 3:181-210

National Climate Centre (1998) Climate Monitoring Bulletin Australia, Issue No. 151 Bureau of Meteorology, Canberra, p 31

Newell RE, Selkirk R, Ebisuzaki W (1982) The Southern Oscillation: sea-surface temperature and wind relationships in a 100-year data set. J Clim 2:357-373

Ogi $H$ (1984) Seabird mortality incidental to the Japanese Salmon gill-net fishery. In: Croxall JP, Evans PGH, Schreiber RW (eds) Status and conservation of the world's seabirds. International Conservation for Bird Preservation, Technical Publication No. 2, Cambridge, p 717-721

Philander SG (1990) El Niño, La Niña and the Southern Oscillation. Academic Press, San Diego

Safina C, Burger J, Gochfeld M, Wagner RH (1988) Evidence for prey limitation of common and roseate tern reproduction. Condor 90:852-859

Shannon LV, Crawford RJM, Duffy DC (1984) Pelagic fisheries and warm events: a comparative study. S Afr J Sci 80:51-60

Southland Conservation Board (1994) Proposed settlement of Ngai Tahu claims to Crown Titi Islands and Codfish Island. Department of Conservation, Invercargill

Spear LB, Ainley DG (1997) Flight behaviour of seabirds in relation to wind direction and wing morphology. Ibis 139 : $221-233$

Spear LB, Ainley DG (1999) Migration routes of Sooty Shearwaters in the Pacific Ocean. Condor 101:205-218

Tanaka H, Ogi H, Tanabe S, Tatsukawa R, Oka N (1986) Bioaccumulation and metabolism of PCBs and DDE in Short-tailed Shearwater Puffinus tenuirostris during it's trans-equatorial migration and in the wintering and breeding grounds. Abiko 147-155

Tennyson A (1990) Seabirds in strife. Royal Forest and Bird, Issue No. 258, 21(4):23-30

Trenberth KE (1990) Recent observed interdecadal climate changes in the Northern Hemisphere. Am Meteorol J 71 : 988-993

Troup AJ (1965) The Southern Oscillation. Q J R Meteorol Soc 91:490-506

Vader W, Barrett RT, Erikstad KE, Strann KB (1990) Differential responses of common and thick-billed murres to a crash in the capelin stock in the southern Barents Sea. Stud Avian Biol 14:175-180

Veit RR, Pyle P, McGowan JA (1996) Ocean warming and long-term change in pelagic bird abundance within the California current system. Mar Ecol Prog Ser 139:11-18

Veit RR, McGowan JA, Ainley DG, Wahls TR, Pyle P (1997) Apex marine predator declines ninety percent in association with changing climate. Global Change Biol 3:23-28 
Walker GT (1924) Correlation in seasonal variations of weather. Mem Ind Meteorol Dep 24:275

Warham J (1996) The behaviour, population biology and physiology of the petrels. Academic Press Ltd, London

Warham J, Wilson G (1982) The size of the sooty shearwater population at the Snares Islands, New Zealand. Notornis 29:23-30

Weimerskirch H, Sagar PM (1996) Diving depths of Sooty Shearwaters Puffinus griseus. Ibis 138:786-788

Editorial responsibility: Otto Kinne (Editor),

Oldendorf/Luhe, Germany
Williams TD, Croxall JP (1990) Is chick fledging weight a good index of food avaiability in seabird populations? Oikos 59:414-416

Wilson E (1979) Titi heritage-the story of the muttonbird islands. Craig Printing Co Ltd, Invercargill

Wooller RD, Bradley JS, Skira IJ, Serventy DL (1990) Reproductive success of Short-tailed Shearwaters Puffinus tenuirostris in relation to their age and breeding success. J Anim Ecol 59:161-170

Submitted: January 26, 1999; Accepted: May 12, 1999 Proofs received from author(s): October 6, 1999 